\title{
PENGARUH PDRB, PENDIDIKAN, KESEHATAN, DAN PENGANGGURAN TERHADAP TINGKAT KEMISKINAN DI JAWA TENGAH (2011-2015)
}

\author{
Aria Bhaswara Mohammad Bintang
}

Email: bhaswara_bintang@live.com

\author{
Nenik Woyanti \\ Departemen IESP Fakultas Ekonomika dan Bisnis Universitas Diponegoro \\ Email:neni346@yahoo.com
}

\begin{abstract}
Abstrak
Tingginya tingkat kemiskinan di Jawa Tengah menunjukkan perkembangan yang tidak dapat diandalkan yang masih belum dapat meningkatkan kesejahteraan secara merata. Oleh karena itu diperlukan analisis untuk mengidentifikasi beberapa faktor yang mempengaruhinya. Tujuan penelitian ini adalah untuk mengetahui beberapa faktor yang mempengaruhi tingkat kemiskinan di 35 Kabupaten / Kota Provinsi Jawa Tengah dari tahun 2011 sampai 2015. Penelitian ini menggunakan data sekunder yang meliputi 35 Kabupaten / Kota di Jawa Tengah berdasarkan data cross section dan dari 2011 sampai dengan 2015 pada data time series. Metode analisis dari penelitian ini adalah Fixed Effect Model (FEM) atau Least Square Dummy Variable (LSDV). Cross section dummy diperlukan karena perbedaan karakteristik dan sumber daya pada masing-masing Kabupaten dan Kota. Hasil penelitian menunjukkan bahwa pertumbuhan PDRB berpengaruh positif dan signifikan terhadap tingkat kemiskinan. Tingkat rata-rata lama sekolah dan tingkat harapan hidup memberikan pengaruh negatif dan signifikan terhadap tingkat kemiskinan. Di sisi lain, tingkat pengangguran memberi pengaruh positif dan signifikan terhadap tingkat kemiskinan.
\end{abstract}

Kata kunci: kemiskinan, pertumbuhan PDRB, rata-rata lama sekolah, tingkat harapan hidup, pengangguran

\begin{abstract}
The high level of poverty in Central Java shows unreliable development that still cannot increase prosperity equally. Hence, analysis is required to identify several factors that affect. This research's purpose is to identify several factors that affect the poverty level of the poverty level of 35 Districts/Cities of Central Java Province from 2011 until 2015. This research use secondary data containing 35 Districts/Cities of Central Java on cross section data and 2011 until 2015 on time series data. The analytical method of this research is Fixed Effect Model (FEM) or Least Square Dummy Variable (LSDV). Cross section dummy is required due the differences of characteristics and resources on each Districs and Cities. The results of this research show that Growth of PDRB gives positive and significant effect for poverty level. The Average School Year and Life Expectancy Rate give negative and significant effect for poverty level. On the other side, Unemployment Level give positive and significant effect for poverty level.
\end{abstract}

Keywords: Poverty, Growth of PDRB, Average School Year, Life Expectancy Rate, Unemployment 


\section{PENDAHULUAN}

Salah satu tujuan pembangunan nasional Indonesia berdasarkan Pembukaan Undang-Undang Dasar 1945 yaitu memajukan kesejahteraan umum. Kesejahteraan umum merupakan kondisi terpenuhinya kebutuhan material, spiritual, dan sosial penduduk negara agar dapat hidup layak dan mampu mengembangkan diri, sehingga dapat melaksanakan fungsi sosial dan ekonominya (BPS, 2016). Kesejahteraan umum di Indonesia dapat digambarkan salah satunya berdasarkan tingkat kemiskinan di Indonesia. Terdapat hubungan negatif antara kesejahteraan umum dengan tingkat kemiskinan di Indonesia. Semakin rendah tingkat kemiskinan menggambarkan semakin tinggi kesejahteraan penduduk.

Provinsi Jawa Tengah merupakan salah satu provinsi yang mempunyai jumlah penduduk terbesar di Indonesia, padahal di provinsi Jawa Tengah sudah banyak mengalami perkembangan baik dari pertumbuhan ekonomi dan juga dari sisi infrastruktur. Persentase jumlah penduduk Jawa Tengah terhadap Pulau Jawa hingga tahun 2015 mencapai sebesar $13,22 \%$, sedangkan persentase jumlah penduduk Pulau Jawa tehadap Indonesia yaitu sebesar $56,81 \%$. Satu pencapaian pembangunan dalam Millenium Development Goals (2015) adalah tercapainya angka kemiskinan $b$ di bawah $10 \%$. Tingkat kemiskinan Provinsi Jawa Tengah dari tahun 2011 hingga 2015 cenderung mengalami penurunan, namun masih masih tergolong tinggi, di mana pada tahun 2011 sebesar $15,8 \%$ kemudian turun menjadi sebesar $14,44 \%$ di tahun 2013, lalu pada tahun 2014 dan 2015 stabil pada angka sebesar $13,58 \%$.

Tujuan dari penelitian ini yaitu menganalisis pengaruh PDRB, pendidikan, kesehatan, dan pengangguran terhadap tingkat kemiskinan di Provinsi Jawa Tengah pada tahun 2011-2015. Alat analisis yang dalam penelitian digunakan adalah Fixed Effect Model (FEM) atau juga dikenal sebagai Least Square Dummy Variable (LSDV).

Kerangka pemikiran penelitian ini adalah bahwa kemiskinan dipengaruhi oleh empat variabel pembangunan ekonomi, yaitu: laju pertumbuhan PDRB, pendidikan, kesehatan dan pengangguran. PDRB adalah sebagai indikator pertumbuhan ekonomi di Jawa Tengah, sedangkan pendidikan dan kesehatan untuk menunjukkan kualitas sumber daya manusia yang mempengaruhi produktivitas, dan pengangguran untuk menggambarkan kemampuan suatu struktur perekonomian dalam penyediaan lapangan pekerjaan yang akan berpengaruh pada kesejahteraan masyarakat.

Produk Domestik Regional Bruto (PDRB) merupakan salah satu indikator yang digunakan untuk mengukur kinerja perekonomian suatu daerah dalam suatu periode.PDRB merupakan jumlah nilai tambah yang dihasilkan oleh seluruh unit usaha pada suatu daerah tertentu dan dapat juga dikatakan sebagai jumlah dari nilai barang dan jasa akhir yang dihasilkan oleh seluruh unit ekonomi (BPS,2016). Menurut Todaro (2013), meskipun tidak memberi jawaban secara otomatis terhadap berbagai macam permasalahan, namun pertumbuhan ekonomi tetap menjadi unsur penting dalam pengentasan kemiskinan. Penelitian yang dilakukan oleh Mariyanti dan Mahfudz (2016) mengenai hubungan pertumbuhan ekonomi dan kemiskinan menyimpulkan adanya hubungan kausalitas antara pertumbuhan ekonomi dan kemiskinan. Menurut Akoum (2008) bahwa negara dengan pertumbuhan ekonomi yang tinggi akan memiliki tingkat kemiskinan yang juga tinggi. Sedangkan Prasad (1998) tidak menemukan hubungan yang konkret antara pertumbuhan ekonomi dan kemiskinan.

Pendidikan telah menjadi kebutuhan pokok bagi seluruh lapisan masyarakat. Menurut Undang-Undang No. 
20 Tahun 2003, yang dimaksud dengan pendidikan ialah usaha sadar dan untuk mewujudkan suasana belajar dan proses pembelajaran agara peserta didik secara aktif mengembangkan potensi dirinya untuk memiliki kekuatan spiritual keagamaan, pengendalian diri, kepribadian, kecerdasan, akhlak mulia, serta keterampilan yang diperlukan diri sendiri, masyarakat, bangsa, dan negara. Todaro (2013) mengemukakan bahwa struktur pendidikan yang berlaku pada suatu daerah dapat mempengaruhi karakter sosial dan ekonomi masyarakat pada daerah yang bersangkutan. Sanz, et al (2017) berpendapat bahwa kemiskinan sangat mungkin dipengaruhi oleh pendidikan. Adanya keterbatasan dalam hal pendidikan akan menyebabkan terhambatnya kesempatan untuk memperoleh pendapatan yang lebih tinggi. Penelitian yang dilakukan oleh Hong dan Pandey (2007) menyimpulkan bahwa penduduk dengan tingkat pendidikan yang lebih tinggi memiliki kemungkinan yang lebih kecil untuk menjadi miskin. Menurut Ataguba, et al (2013) salah satu penentu penurunan tingkat kemiskinan adalah faktor pendidikan.

Selain pendidikan, kesehatan juga menjadi kebutuhan pokok bagi seluruh lapisan masyarakat. Menurut World Health Organization (WHO), yang dimaksud dengan sehat yaitu keadaan sejahtera secara fisik, mental, dan sosial yang memungkinkan individu hidup secara produktif baik dalam aspek sosial maupun aspek ekonomi. Dalam Undang-Undang No. 36 Tahun 2009 dituliskan bahwa setiap orang berhak atas kesehatan. Dalam hal ini, Angka Harapan Hidup merupakan alat untuk mengevaluasi kinerja pemerintah dalam meningkatkan kesejahteraan penduduk pada umumnya, dan derajat kesehatan pada khususnya. Menurut Mariyanti dan Mahfudz (2016), dalam konteks kesehatan, konsumsi nutrisi yang buruk dapat memberikan dampak pada tingkat kemiskinan sehingga negara yang penduduknya sehat juga diyakini akan memiliki perekonomian yang "sehat". Menurut Wyk dan Bradshaw (2017) masyarakat yang memiliki Angka Harapan Hidup yang baik akan meningkatkan kesempatan untuk memperoleh pendapatan yang lebih tinggi Sedangkan menurut Ataguba, et al (2013) kesehatan merupakan salah satu faktor penting dalam mengurangi kemiskinan. Sejalan dengan hasil tersebut, Bakhtiari dan Meisami (2009) dalam penelitiannya memperoleh hasil yaitu adanya peningkatan di bidang kesehatan akan menurunkan tingkat kemiskinan.

Pengangguran merupakan permasalahan yang dihadapi oleh berbagai daerah, termasuk Provinsi Jawa Tengah. Menurut International Labour Organization, pengangguran didefinisikan sebagai mereka yang termasuk kelompok penduduk usia kerja yang selama periode tertentu tidak bekerja, dan bersedia menerima pekerjaan, serta sedang mencari pekerjaan. Sedangkan menurut Badan Pusat Statistik (2016), yang dimaksud dengan pengangguran ialah jumlah angkatan kerja yang tidak bekerja dan mencari pekerjaan.Menurut Lundahl (2005), pertumbuhan penduduk yang tinggi artinya aka nada peningkatan angkatan kerja, sehingga perlu ada peningkatan jumlah lapangan kerja.Jika tidak, dampak yang ditimbulkan pada jangka panjang yaitu kemiskinan yang meningkat. Sependapat dengan Lundahl, O'Campo (2015) menyatakan bahwa bukti-bukti empiris selalu menunjukkan bahwa pengangguran secara langsung akan berdampak kepada meningkatnya kemiskinan.Penelitian yang dilakukan Ukpere dan Slabbert (2009) memperoleh hasil bahwa pengangguran pada era globalisasi berpengaruh positif dan signifikan terhadap tingkat kemiskinan.

\section{METODE PENELITIAN Variabel Penelitian}

Variabel dependen penelitian ini adalah Tingkat Kemiskinan dengan 
menggunakan satuan persen. Variabel independen penelitian ini meliputi:

1. Laju pertumbuhan PDRB dengan satuan persen.

2. Pendidikan yang direpresentasikan oleh rata-rata lama sekolah dengan satuan tahun.

3. Kesehatan yang direpresentasikan oleh angka harapan hidup waktu lahir dengan satuan tahun

4. Pengangguran yang direpresentasikan oleh tingkat pengangguran terbuka dengan satuan persen.

Data yang digunakan berasal dari Badan Pusat Statistik Provinsi Jawa Tengah periode 2011 hingga 2015.

\section{Metode Analisis}

Analisis yang digunakan dalam penelitian ini adalah Fixed Effect Model (FEM) atau disebut juga Least Square Dummy Variable (LSDV). Penggunaan dummy wilayah pada model penelitian bertujuan untuk melihat perbedaan karakteristik dan perbedaan perkembangan kemiskinan pada setiap Kabupapten/Kota Di Provinsi Jawa Tengah. Model estimasi regresi yang digunakan dapat dituliskan sebagai berikut:

$\mathrm{P}_{\mathrm{it}}=\alpha_{0}+\alpha_{1} \mathrm{Y}_{\mathrm{it}}+\alpha_{2} \mathrm{E}_{\mathrm{it}}+\alpha_{3} \mathrm{H}_{\mathrm{it}}+\alpha_{4} \mathrm{U}_{\mathrm{it}}+$ $\gamma_{1} \mathrm{D}_{1}+\gamma_{2} \mathrm{D}_{2}+\gamma_{3} \mathrm{D}_{3}+\gamma_{4} \mathrm{D}_{4}+\gamma_{5} \mathrm{D}_{5}+\gamma_{6} \mathrm{D}_{6}+$ $\gamma_{7} \mathrm{D}_{7}+\gamma_{8} \mathrm{D}_{8}+\gamma_{9} \mathrm{D}_{9}+\gamma_{10} \mathrm{D}_{10}+\gamma_{11} \mathrm{D}_{11}+$ $\gamma_{12} \mathrm{D}_{12}+\gamma_{13} \mathrm{D}_{13}+\gamma_{14} \mathrm{D}_{14}+\gamma_{15} \mathrm{D}_{15}+\gamma_{16} \mathrm{D}_{16}$ $+\gamma_{17} \mathrm{D}_{17}+\gamma_{18} \mathrm{D}_{18}+\gamma_{19} \mathrm{D}_{19}+\gamma_{20} \mathrm{D}_{20}+$ $\gamma_{21} \mathrm{D}_{21}+\gamma_{22} \mathrm{D}_{22}+\gamma_{23} \mathrm{D}_{23}+\gamma_{24} \mathrm{D}_{24}+\gamma_{25} \mathrm{D}_{25}$ $+\gamma_{26} \mathrm{D}_{26}+\gamma_{27} \mathrm{D}_{27}+\gamma_{28} \mathrm{D}_{28}+\gamma_{29} \mathrm{D}_{29}+$ $\gamma_{30} \mathrm{D}_{30}+\gamma_{31} \mathrm{D}_{31}+\gamma_{32} \mathrm{D}_{32}+\gamma_{33} \mathrm{D}_{33}+\gamma_{34} \mathrm{D}_{34}$ $+\gamma_{35} \mathrm{D}_{35}+\mu_{\mathrm{it}}$

\section{Dimana Padalah Tingkat} Kemiskinan, Y adalah notasi dari laju pertumbuhan produk domestik regional bruto, E adalah notasi dari rata-rata lama sekolah, $\mathrm{H}$ adalah notasi dari angka harapan hidup waktu lahir, D merupakan notasi yang merepresentasikan dummy wilayah setiap Kabupaten/Kota di Provinsi Jawa Tengah, $\alpha_{0}$ merupakan notasi dari intersep, $\alpha_{1-4}$ merupakan koefisien regresi variabel independen, $\gamma_{1-35}$ merupakan koefisien dummy wilayah,dan $\mu$ merupakan error. Terhadap hasil analisis regresi yang diperoleh dengan model tersebut dilakukan pengujian ekonometrik dan uji statistik.

\section{HASIL PENELITIAN DAN PEMBA- HASAN}

Provinsi Jawa Tengah meliputi 29 Kabupaten dan 6 kota, yaitu Kabupaten Cilacap, Kabupaten Cilacap, Banyumas, Purbalingga, Banjarnegara, Kebumen, Perworejo, Wonosobo, Magelang, Boyolali, Klaten, Sukoharjo, Wonogiri, Karanganyar, Sragen, Gobogan, Blora, RembangPati, Kudus, Jepara, Demak, Semarang, Temanggung, Kendal, Batang, Pekalongan, Pemalang, Tegal dan Brebes serta Kota Magelang, Surakarta, Salatiga, Semarang, Pekalongan, dan Tegal. Luas wilayah Jawa Tengah 3.254.412 ha atau $25,4 \%$ dari luas pulau jawa dan setara $1,7 \%$ dari luas wilayah Indonesia.Berdasarkan hasil Sensus Ekonomi Nasional, jumlah penduduk Provinsi Jawa dari tahun 2010 hingga 2015 mengalami peningkatan. Pada Tahun 2010, jumlah penduduk Provinsi Jawa Tengah mencapai sekitar 32.443.890 jiwa dengan persentase mencapai $13,6 \%$ dari penduduk Indonesia secara keseluruhan. Sedangkan jumlah penduduk pada tahun 2015 mencapai sekitar 33.774.140 jiwa atau mencapai $13,22 \%$ dari seluruh penduduk Indonesia

Angka Kemiskinan di setiap Kabupaten/Kota cenderung menurun dari tahun ke tahun. Hingga tahun 2015, Angka Kemiskinan Provinsi Jawa Tengah mencapai sebesar 13,58\%. Kabupaten dengan Angka Kemiskinan terendah pada tahun 2015 yaitu Kabupaten Kudus sebesar $7,73 \%$, sedangkan yang tertinggi ialah Kabupaten Kebumen sebesar 20,44\%. Kota dengan Angka Kemiskinan terendah yaitu Kota Semarang sebesar 4,97\%, sedangkan yang tertinggi adalah Kota Surakarta sebesar $10,89 \%$. 
PDRB Provinsi Jawa Tengah selalu mengalami peningkatan dari tahun ke tahun. Pada tahun 2011 PDRB Provinsi Jawa Tengah mencapai sekitar Rp. 656.218.130.000,- hingga pada tahun 2015 meningkat menjadi sekitar Rp. 806.609.020.000,-. Laju pertumbuhan PDRB Provinsi Jawa Tengah fluktuatif cenderung meningkat. Pada tahun 2011 laju pertumbuhan PDRB mencapai 5,30\%, akan tetapi pada tahun 2013 turun menjadi sebesar 5,11\%. Pada tahun 2015 kembali naik menjadi sebesar 5,44\%.

Rata-Rata Lama Sekolah secara umum di Provinsi Jawa Tengah maupun secara spesifik cenderung meningkat dari tahun ke tahun. Pada tahun 2011 Rata-Rata Lama Sekolah Provinsi Jawa Tengah berada di angka 6,74 tahun, hingga pada tahun 2015 meningkat menjadi sebesar 7,03 tahun. Pada tahun 2015, kabupaten dengan rata-rata lama sekolah tertinggi adalah Kabupaten Karanganyar sebesar 8,48 tahun, sedangkan kabupaten dengan rata-rata lama sekolah terendah adalah Kabupaten Brebes sebesar 5,88 tahun. Kota dengan rata-rata lama sekolah tertinggi adalah Kota Surakarta sebesar 10,36 tahun, sedangkan kota dengan ratarata lama sekolah yang terendah adalah Kota Tegal sebesar 8,27 tahun.

Angka Harapan Hidup Saat Lahir pada tiap Kabupaten/Kota di Provinsi Jawa Tengah, secara umum maupun secara spesifik cenderung mengalami peningkatan dari tahun ke tahun. Pada tahun 2011 Angka Harapan Hidup Saat Lahir Provinsi Jawa Tengah yaitu 72,91 tahun, hingga pada tahun 2015 meningkat menjadi sebesar 73,96 tahun. Pada tahun 2015, Kabupaten dengan Angka Harapan Hidup Saat Lahir tertinggi yaitu Kabupaten Sukoharjo sebesar 77,46 tahun, sedangkan yang terendah adalah Kabupaten Brebes sebesar 68,2 tahun. Kota Semarang adalah kota dengan angka harapan hidup tertinggi, yaitu sebesar 77,2 tahun, sedangkan kota dengan harapan hidup yang terendah adalah Pekalongan sebesar 74,11.
Rata-rata tingkat pengangguran terbuka Provinsi Jawa Tengah mencapai $5,87 \%$. Kabupaten Temanggung adalah kabupaten yang memiliki rata-rata tingkat pengangguran terbuka terendah adalah Kabupaten Temanggung sebesar 3,3\%, sedangkan kabupaten dengan tingkat pengangguran terbuka tertinggi adalah Kabupaten Brebes sebesar 8,99\%. Kota yang memiliki rata-rata tingkat pengangguran terbuka terendah adalah Kota Pekalongan sebesar 5,11\%, sedangkan kota yang memiliki tingkat pengangguran terbuka tertinggi adalah Kota Tegal sebesar 9,02\%.

Hasil estimasi model regresi dengan metode Least Square Dummy Variable adalah sebagai berikut:

$\mathrm{P}_{\mathrm{it}}=7,497+0,1819 \mathrm{Y}_{\mathrm{it}}-2,5277 \mathrm{E}_{\mathrm{it}}-$ $2,7423 \mathrm{H}_{\mathrm{it}}+0,1027 \mathrm{U}_{\mathrm{it}}-4,5546 \mathrm{D}_{1}+$ $0,8531 \mathrm{D}_{2}+1,3081 \mathrm{D}_{3}-0,7061 \mathrm{D}_{4}+$ $1,7297 \mathrm{D}_{5}+1,4202 \mathrm{D}_{6}-4,1806 \mathrm{D}_{7}-$ $3,8003 \mathrm{D}_{8}+1,7844 \mathrm{D}_{9}+9,4463 \mathrm{D}_{10}+$ $7,2672 \mathrm{D}_{11}+1,7988 \mathrm{D}_{12}+8,9854 \mathrm{D}_{13}+$ $3,1462 \mathrm{D}_{14}-1,5155 \mathrm{D}_{15}-3,8184 \mathrm{D}_{16}+$ $5,3952 \mathrm{D}_{17}-0,2568 \mathrm{D}_{18}+1,7524 \mathrm{D}_{19}-$ $1,1996 \mathrm{D}_{20}+4,3096 \mathrm{D}_{21}-1,5031 \mathrm{D}_{22}-$ $1,0802 D_{23}-3,7679 D_{24}-4,9103 D_{25}-$ $5,2575 \mathrm{D}_{26}-3,3428 \mathrm{D}_{27}-16,7332 \mathrm{D}_{28}-$ $15,1776 \mathrm{D}_{29}+9,5039 \mathrm{D}_{30}+12,6418 \mathrm{D}_{31}+$ $4,1462 \mathrm{D}_{32}+6,2097 \mathrm{D}_{33}-3,8486 \mathrm{D}_{34}-$ $3,5277 \mathrm{D}_{35}+\mu_{\mathrm{it}}$

Model regresi dalam penelitian ini telah memenuhi asumsi klasik, yaitu BLUE (Best Linear Unbiased Estimate). Variabel independen dalam model, yaitu laju pertumbuhan PDRB, Pendidikan, Kesehatan, dan Pengangguran berpengaruh terhadap Tingkat Kemiskinan secara signifikan $(\alpha=5 \%)$. Hasil uji koefisien determinasi menunjukkan angka sebesar 0,9878. Sehingga dapat dikatakan bahwa sebanyak $98,78 \%$ variasi tingkat kemiskinan dapat dijelaskan oleh variasi laju pertumbuhan PDRB, pendidikan, kesehatan, dan pengangguran sedangkan $1,22 \%$ dijelaskan oleh variabel lain di luar model. 
PDRB memiliki pengaruh yang positif dan signifikan terhadap tingkat kemiskinan di Provinsi Jawa Tengah. Berdasarkan hasil regresi, koefisien PDRB adalah sebesar 0,181. Artinya kenaikan PDRB sebesar $1 \%$ akan menyebabkan peningkatan pada Tingkat Kemiskinan sebesar $0,181 \%$.Penelitian yang dilakukan oleh Akoum (2008) juga menjelaskan bahwa beberapa negara berkembang yang memiliki tingkat pertumbuhan ekonomi yang tinggi tidak selalu berhasil dalam mengurangi tingkat kemiskinan.Artinya, sebagian besar negara berkembang belum berhasil mencapai pertumbuhan ekonomi yang dikategorikan berkualitas, atau boleh jadi tidak dirasakan oleh masyarakat yang tergolong miskin. Penelitian yang dilakukan Prasad (1998) memperoleh hasil yang sama, yaitu tidak ada hubungan yang konkret antara pertumbuhan ekonomi dan tingkat kemiskinan. Beberapa negara dengan tingkat pertumbuhan ekonomi yang tinggi juga memiliki tingkat kemiskinan yang tinggi.

Menurut Prasad (1998) partumbuhan ekonomi yang disertai dengan stabilitas pada aspek sosial, institusional, dan politik suatu negara atau daerah akan berpotensi mengurangi tingkat kemiskinan dalam jangka panjang. Goff dan Singh (2014) juga mengemukakan bahwa pertumbuhan ekonomi suatu negara atau daerah dapat mengurangi tingkat kemiskinan jika unsur kelembagaan negara atau daerah tersebut tertata dengan baik.

Pendidikan yang direpresentasikan oleh rata-rata lama sekolah memiliki pengaruh negatif dan signifikan terhadap Tingkat Kemiskinan Provinsi Jawa Tengah. Berdasarkan hasil analisis regresi, nilai koefisien pendidikan sebesar-2,527. Artinya setiap kenaikan 1 tahun pada ratarata lama sekolah memberikan dampak turunnya tingkat kemiskinan sebesar 2,527\%. Hasil penelitian ini sejalan dengan penelitian Bakhtiari dan Meisami (2009) yang menyatakan bahwa adanya peningkatan di bidang pendidikan akan menurunkan tingkat kemiskinan. Sependapat dengan Bakhtiari dan Meisami, penelitian yang dilakukan oleh Ataguba, et al (2013) juga menyatakan bahwa salah satu faktor penentu menurunnya tingkat kemiskinan ialah pendidikan. Sejalan dengan hasil penelitian di atas, Mariyanti dan Mahfudz (2016) memperoleh hasil yaitu pendidikan berpengaruh terhadap tingkat kemiskinan.

Menurut Schultz (1961) dan Becker (1965), pendidikan merupakan investasi yang dilakukan di masa kini oleh sumber daya manusia dengan tujuan memperoleh hasilnya di masa yang akan datang. Sependapat dengan Schultz dan Becker, Todaro (2013) menyatakan bahwa salah satu modal manusia yang paling penting adalah pendidikan formal.Semakin baik akses masyarakat dalam memperoleh pendidikan, semakin besar pula kesempatan mereka untuk meningkatkan kesejahteraan.Sehingga pembangunan yang terfokus pada sumber daya manusia bisa tercapai. Sedangkan menurut Hong dan Pandey (2007), penduduk dengan tingkat pendidikan yang tinggi akan memiliki kemungkinan yang kecil untuk menjadi miskin.

Kesehatan yang direpresentasikan oleh angka harapan hidup saat lahir memiliki pengaruh yang negatif dan signifikan terhadap Tingkat Kemiskinan Provinsi Jawa Tengah.Berdasarkan hasil regresi, nilai koefisien Kesehatan ialah sebesar -2,742. Artinya setiap kenaikan angka harapan hidup saat lahir sebesar 1 tahun akan memberikan dampak penurunan tingkat kemiskinan sebesar 2,742\%. Hasil penelitian ini sejalan dengan penelitian Bakhtiari dan Meisami (2009) yang menyatakan bahwa adanya peningkatan di bidang kesehatan akan berpotensi menurunkan tingkat kemiskinan. Sejalan dengan hasil ini, penelitian Ataguba, et al (2013) memperoleh hasil yaitu salah satu faktor penentu menurunnya tingkat kemiskinan ialah kesehatan.Mariyanti dan Mahfudz 
(2016) memperoleh hasil yang juga sama, yaitu tingkat kesehatan berpengaruh terhadap tingkat kemiskinan. Hal ini dapat diartikan bahwa apabila kualitas kesehatan masyarakat Jawa Tengah meningkat, maka Tingkat Kemiskinan Jawa Tengah diyakini dapat menurun.

Strauss dan Thomas (1995) berpendapat bahwa ada keterkaitan yang kuat antara kesehatan dengan kemiskinan. Kesehatan individu menentukan produktivitas sehingga semakin rendah tingkat kesehatan, semakin besar kemungkinan individu untuk terjebak dalam kemiskinan. Upaya pemerintah dalam memperbaiki sarana dan prasarana kesehatan cukup penting dalam mengentaskan kemiskinan (Arsyad, 2010). Peningkatan kualitas pelayanan kesehatan dalam jangka panjang akan meningkatkan produktivitas, khususnya bagi masyarakat yang tergolong kurang mampu. Menurut Topuz (2009) bantuan kesehatan dari pemerintah seperti asuransi dapat secara efektif mengurangi tingkat kemiskinan.

Pengangguran yang direpresentasikan oleh Tingkat Pengangguran Terbuka (TPT) memiliki pengaruh yang positif dan signifikan terhadap tingkat kemiskinan Provinsi Jawa Tengah. Berdasarkan hasil analisis regresi, nilai koefiisien pengangguran adalah sebesar 0,102. Artinya setiap kenaikan Tingkat Pengangguran Terbuka sebesar 1\% akan memberikan dampak naiknya Tingkat Kemiskinan sebesar 0,102\%. Hasil penelitian ini sesuai dengan penelitian Hong dan Pandey (2007) yang menyatakan bahwa pengangguran berpengaruh secara positif terhadap kemiskinan. Hasil yang sama juga diperoleh Ukpere dan Slabbert (2009) yaitu pengangguran di era globalisasi berpengaruh secara positif dan signifikan terhadap kemiskinan. Hasil ini dapat diartikan bahwa ketika tingkat pengangguran naik, tingkat kemiskinan juga akan meningkat.
Menurut Agénor (2004) karena keterkaitannya yang sangat kuat, selalu terjadi trade-off antara pengangguran dan kemiskinan. Tingkat pengangguran yang tinggi akan berimbas pada meningkatnya tingkat kemiskinan. Sependapat dengan Agénor, Engbersendkk.(2006) berpendapat bahwa keterkaitan antara pengangguran dan kemiskinan yaitu kemiskinan merupakan efek jangka panjang dari pengangguran. Sedangkan menurut Sukirno (2012), mengatakan bahwa permasalahan pengangguran tidak bisa diselesaikan begitu saja melalui mekanisme pasar, sehingga perlu adanya campur tangan pemerintah dalam mengatasi permasalahan tersebut.

\section{PENUTUP}

\section{Kesimpulan}

Berdasarkan penelitian terhadap 29 Kabupaten di Provinsi Jawa Tengah, kabupaten dengan perkembangan tingkat kemiskinan yang tertinggi adalah Kabupaten Tegal, sedangkan kabupaten dengan perkembangan tingkat kemiskinan yang terendah adalah Kabupaten Pati. Dari 6 Kota di Provinsi Jawa Tengah, kota dengan perkembangan Tingkat Kemiskinan tertinggi adalah Kota Surakarta, sedangkan Kota dengan perkembangan Tingkat Kemiskinan yang paling rendah yaitu Kota Tegal.

PDRB berpengaruh positif terhadap Tingkat Kemiskinan pada 35 Kabupaten/Kota di Provinsi Jawa Tengah. Hasil ini mengindikasikan pertumbuhan ekonomi tidak merata dan didominasi oleh kontribusi masyarakat golongan berpendapatan tinggi. Pertumbuhan ekonomi yang tidak diikuti oleh pemerataan akan mengakibatkan ketimpangan ekonomi pada suatu daerah.

Pendidikan yang direpresentasikan oleh Rata-Rata Lama Sekolah berpengaruh negatif terhadap Tingkat Kemiskinan pada 35 Kabupaten/Kota di Provinsi Jawa 
Tengah.Hasil penelitian ini sesuai dengan pendapat Todaro yang menyatakan bahwa pendidikan formal merupakan modal manusia yang penting dalam mencapai kesejahteraan. Semakin baik akses masyarakat dalam memperoleh pendidikan, semakin besar pula kesempatan masyarakat dalam meningkatkan kesejahteraan.

Kesehatan yang direpresentasikan oleh Angka Harapan Hidup Saat Lahir berpengaruh negatif terhadap Tingkat Kemiskinan pada 35 Kabupaten/Kota di Provinsi Jawa Tengah. Peningkatan dalam bidang kesehatan akan berpotensi mengurangi tingkat kemiskinan. Kesehatan berkaitan dengan produktivitas. Kesehatan yang baik akan meningkatkan daya kerja sehingga akan meningkatkan output.

Variabel Pengangguran yang direpresentasikan oleh Tingkat Pengangguran Terbuka (TPT) memiliki pengaruh yang positif dan signifikan terhadap Tingkat Kemiskinan di Provinsi Jawa Tengah. Hasil penelitian sejalan dengan pendapat Todaro (2013) yang menyatakan bahwa adanya masalah pengangguran berkaitan erat dengan kemakmuran masyarakat.

\section{REFERENSI}

Agénor, P.R. (2004). UnemploymentPoverty Trade-Off. World Bank Poverty Reduction and Economic Management Division.

Akoum, I. F. (2008). Globalization, growth, and poverty: the missing link. International Journal of Social Economics, 35(4), 226-238.

Arsyad, L. (2010). Ekonomi Pembangunan. Yogyakarta: UPP STIM YKPN.

Badan Pusat Statistik Provinsi Jawa Tengah. http://jateng.bps.go.id
Bakhtiari, S., \& Meisami, H. (2010). An empirical investigation of the effects of health and education on income distribution and poverty in Islamic countries. International Journal of Social Economics, 37(4), 293-301.

Ele-Ojo Ataguba, J., Eme Ichoku, H., \& Fonta, W. M. (2013). Multidimensional poverty assessment: applying the capability approach. International Journal of Social Economics, 40(4), 331-354.

Engbersen, G., Schuyt, K., Timmer, J., \& Van Waarden, F. (2006). Cultures of unemployment: A comparative look at long-term unemployment and urban poverty. Amsterdam University Press.

Gujarati, D., \& Porter, D.C., (2010). Basic Econometrics. New York: McGraw Hill.

Le Goff, M., \& Singh, R. J. (2014). Does trade reduce poverty? A view from Africa. Journal of African Trade, l(1), 5-14.

Lundahl, M. (2005). Poverty: 'No Place is Too Exalted for The Preaching of These Doctrines'. Abingdon: Routledge Publishing.

Mariyanti, T., Mariyanti, T., Mahfudz, A. A., \& Mahfudz, A. A. (2016). Dynamic circular causation model in poverty alleviation: Empirical evidence from Indonesia. Humanomics, 32(3), 275-299.

O'Campo, P., Molnar, A., Ng, E., Renahy, E., Mitchell, C., Shankardass, K., \& Muntaner, C. (2015). Social welfare matters: A realist review of when, how, and why unemployment insurance impacts poverty and health. Social Science \& Medicine, 132, 88-94. 
Pillay-van Wyk, V., \& Bradshaw, D. (2017). Mortality and socioeconomic status: the vicious cycle between poverty and ill health. The Lancet Global Health, 5(9), e851-e852.

Prasad, B. C. (1998). The woes of economic reform: poverty and income inequality in Fiji. International Journal of Social Economics, 25(6/7/8), 1073-1094.

Republik Indonesia. Undang-Undang Dasar Negara Republik Indonesia 1945.

Republik Indonesia.Undang-Undang No. 20 Tahun 2003 tentang Sistem Pendidikan Nasional. Lembaran Negara Tahun 2003 No. 4301. Sekretaris Negara Republik Indonesia.

Republik Indonesia.Undang-Undang No. 36 Tahun 2009 tentang Kesehatan. Lembaran Negara Tahun 2009 No. 5063. Sekretaris Negara Republik Indonesia.

Riduwan. (2008). Dasar-dasar Statistika. Bandung: Alfa Beta.

Sanz, R., Peris, J. A., \& Escámez, J. (2017). Higher education in the fight against poverty from the capabilities approach: The case of Spain. Journal of Innovation \& Knowledge, 2(2), 53-66.

Spicker, P. (2002). Poverty and The Welfare State. London: Catalyst Working Paper.

Strauss, J., \& Thomas, D. (1995). Human resources: Empirical modeling of household and family decisions. Handbook of development economics, 3, 1883-2023.

Sukirno, S. (2012). Makroekonomi: Teori Pengantar. Jakarta. Raja Grafindo Persada.
Sumodiningrat, G. (2003). Ekonometrika Pengantar. Yogyakarta: BPFE UGM.

Todaro, M.P. (2013). Pembangunan Ekonomi. Jakarta: Penerbit Erlangga.

Topuz, S. K. (2009). General Tendency of Social Spending in Turkey: 20012009 on Education, Health, and Other Insurances. Alternatif Politika, 1(1),115-136.

Ukpere, W. I., \& Slabbert, A. D. (2009). A relationship between current globalisation, unemployment, inequality and poverty. International Journal of Social Economics, $36(1 / 2), 37-46$.

Young P. Hong, P., \& Pandey, S. (2007). Human capital as structural vulnerability of US poverty. Equal Opportunities International, 26(1), $18-43$. 